economic relations with the Soviet Union on which the governments concerned can agree, or agree to disagree. The more public that process, the more easily the United States could abandon as it must its sanctions against companies in Western Europe without losing face.

Agreement is too much to ask for, but a basis for civilized disagreement should be attainable. The underlying issue is what kind of relationship should obtain between the industrialized West and the industrialized East, partners in a more vexing dispute than over a mere pipeline. A few things are agreed, at least formally: there should be negotiations on strategic arms control, and neither side will sell defence equipment to the other. Two other issues are more fuzzy: the extent to which personal freedom is subordinate to or the basis for the integrity of the state, and the part that should be played in such a tense relationship by what would otherwise be considered normal commercial and cultural relationships. Broadly speaking, the governments of West and East differ radically on the first question (which is why they are at loggerheads), but the West is divided among itself on the second. It is possible to argue that the restraint of commerce will force illiberal regimes to become more liberal, but also that the opposite is the truth. The perplexity of British governments about the encouragement of sport in the Republic of South Africa is a proof that historical precedent is not a sure guide.

In such circumstances, the only acceptable basis for an understanding between the disputants of the West is that they should all know clearly where they stand on the restraint of commerce and of cultural relations and (knowing the hazards of ballot-box democracy) should be able to lay odds about where they may stand in future. On the face of things, there is much to be said for Andrei Sakharov's position (see page 199) that the questions of strategic arms control and of human rights (the nature of democracy) should be uncoupled and that the principle should also be extended to uncouple commercial relations on nonmilitary commodities (such as natural gas) from the issue of personal liberty. For once restraint has gone so far that the provision of pipeline equipment is not allowed, the time would soon arrive when even the sale of ostentatiously unstrategic commodities (cereals, say) to the Soviet Union would be disallowed. Paper clips could just as easily be embargoed.

Ostensibly, none of this has much to do with the scientific community, but the contrary is the truth. The tale of how Sir Humphry Davy went on a scientific jaunt (with his new bride) through mainland Europe at the height of the Napoleonic Wars is almost too well known, while the fact that Pugwash could safely meet in Warsaw this August can easily be discounted on the grounds that it is no longer in a position to risk giving offence. Protests among Australian biochemists and other professional people that the federal government should not have put last month's meeting of biochemists at Perth in hazard by denying visas to two Soviet of ficials travelling as scientists are more to the point, if only because they illustrate how initimately government officials rather than professionals are now involved in the judgement of what should be done. (To its credit, the Australian National Academy of Sciences has done everything that might have been expected of it to protest.)

But such issues are too important to be left to government officials. Professional people in the strict sense should have more say. Natural scientists could (and therefore should) argue that their lives would be more interesting and therefore more productive if there were less, not more restraint. Economists (regarded as scientists proper in many places) have much to say about the fructifying all-round benefits of more trade, whatever its nature or with whom. Historians (also still considered to be professional scientists in most of mainland Europe) have important information to contribute about the unfolding of enduring events. If professional people are serious in their protestations that the present world is dangerous, they would be well-advised to turn their energies from saying that nuclear war would be cataclysmic to showing how to solve the more subtle but more urgent problem of East-West relations which has so perplexed the most powerful governments in the past few months.

\section{Doing one's thing}

What do the British Association, ICSU and the Falkland Islands have in common? Distraction.

Crisis is not everybody's agenda, and the British Association for the Advancement of Science duly met last week at the University of Liverpool for its annual jamboree. To nobody's surprise after 150 similar occasions, there were few surprises. Thus Dr Beverly Halstead rehearsed his previously advertised objections to cladistics, Dr W. Eldridge (Gould's collaborator on punctuated equilibrium, and now curator of fossils at the New York Museum of Natural History) replied and the London Times earned a familiar rebuke from Sir Andrew Huxley for having reported the affair as if it had sprung up anew. Most of those listening to the debate, like those attending the meeting as a whole, will have found the experience rewarding (for otherwise they would not have chosen to go). The British Association itself is in a more serious dilemma: it purports to carry the message from research laboratories to the world at large (and many daily newspapers still behave as if that were the case). For next year's meeting, the association is promising that it will have forged stronger relationships with learned societies in the United Kingdom, in the hope that its message will be more pointed. (There will still, of course, be anxieties about money.) Why does not this venerable institution stick to what it does well and have the courage to let others judge whether there are wider benefits and what they are?

The meeting of the International Council of Scientific Unions (KSU) at Cambridge (England) this week will have seemed to its participants to be in quite a different case. Should mainland China be admitted in preference to Taiwan (yes) and if so how (no terms specified in advance)? What should be done about the prospect that thoroughly international conferences will henceforth be impossible because of the assumption by governments that they should be consulted in advance? (The government of Australia last week gave the Australian delegation to the ICSU meeting terms of reference wide enough to be a basis for almost any negotiation at Cambridge, but added the proviso that in future is should have a hand in planning conferences of this kind). And Sir John Kendrew (once secretary-general of the union) was duly appointed president for the next three years. The international union is also short of money, partly at least because it is trying to accomplish goals for which it was not created.

The Falkland Islands are in much the same case. Earlier this week in London, Lord Shackleton (truly a relative of the polar explorer) produced for the British government (and the public gaze) his latest report on the economic prospects for these recently disputed islands. (The British government seems to have gone to war earlier in the year without having read the earlier version of the report, published in 1976.) Some of the recommendations are predictable - the only usable runway on the islands, for example, should be extended to 8,500 feet, thus allowing high-performance military aircraft as well as heavy civil transports to land safely. The proposed deep-water jetty is more of a surprise, as is the proposal that the ownership of land should be transferred, as is only just, to those who work it. In present circumstance, Lord Shackleton's proposal that there should indenfintely be a military garrison on the Falklands and that there should be a development agency modestly to encourage low-technology industries (fishing, knitting and the like) will similarly not cause consternation.

Predictably what remains unsaid is that the Falkland Islands, like the British Association for the Advancement of Science and the International Council of Scientific Unions, cannot be allowed to find their own level in the scheme of things (serving the membership or making arrangements that enable science to function internationally) because of external circumstances, the recent conflict, the shortage of money and the ubiquity of political considerations respectively. Is it not high time that such institutions (even islands) were allowed to get on with what they can do, and were not expected to do what is beyond them? 